\title{
Changing patterns of respiratory disease in HIV positive patients in a referral centre in the United Kingdom between 1986-7 and 1990-1
}

\author{
A D Pitkin, A D Grant, N M Foley, R F Miller
}

\begin{abstract}
Background Respiratory illness is a significant contributor to morbidity and mortality in patients with human immunodeficiency virus (HIV) infection and the acquired immunodeficiency syndrome (AIDS). It has been suggested that Pneumocystis carinii pneumonia is no longer the most frequent cause of respiratory disease in this group because of widespread use of prophylaxis and antiretroviral drugs.
\end{abstract}

Methods A retrospective comparison of the diagnoses in HIV 1 antibody positive patients with respiratory illness admitted to a major UK centre in $1986-7$ and 1990-1 was carried out to identify changes in patterns of respiratory disease.

Results In the 1986-7 period there were 73 patients, of whom none received zidovudine or prophylaxis for pneumocystis pneumonia while in the 1990-1 period there were 122 patients. One hundred and ninety patients (98\%) were male homosexuals. Pneumocystis pneumonia remained the commonest respiratory disease, comprising $68 \%$ of all diagnoses in the $1986-7$ period and $48 \%$ in the $1990-1$ period. Bacterial infections (bronchitis and pneumonia) were seen more commonly in the $1990-1$ period (23\%) than in the $1986-7$ period $(14 \%)$, as was pulmonary Kaposi's sarcoma (12\% in $1990-1$ and $4 \%$ in 1986-7). Mycobacterial infection remained uncommon $(4 \%$ in $1986-7$ and $6 \cdot 5 \%$ in 1990-1).

Conclusion Despite widespread use of zidovudine and prophylaxis, pneumocystis pneumonia remains the commonest respiratory disease in homosexual men.

Medicine, University College London School of Medicine, Middlesex Hospital, London W1N 8AA A D Pitkin

A D Grant

N M Foley

R F Miller

Reprint requests to: Dr R F Miller

Received 19 March 1992 Returned to authors 5 May 1992

Revised version received 22 September 1992

Accepted 6 October 1992 is becoming less common than other infectious and non-infectious respiratory problems in HIV positive patients. ${ }^{45}$ In this study we have compared our previously published experience of respiratory illness in HIV posi-
Recently it has been suggested that as a consequence of effective prophylaxis with nebu- tive patients between 1986 and $1987^{6}$ with recent experience between 1990 and 1991 to identify changes in the patterns of HIV associated respiratory disease.

\section{Patients and methods}

We studied consecutive HIV antibody positive patients admitted for respiratory investigations including bronchoscopy over the periods July 1986 to October 1987, and December 1990 to November 1991. All patients had respiratory symptoms including cough and dyspnoea; some also had fever, chest pain, or sputum expectoration. Since 1985 all HIV antibody positive patients admitted to the Middlesex Hospital have been under the care of a respiratory physician.

In each patient the diagnosis obtained by microbiological and cytological or histopathological examination of bronchoalveolar lavage fluid (and transbronchial biopsy in patients in the 1986-7 study) or percutaneous or open lung biopsy was recorded, together with the final clinical diagnosis. The methods used for fibreoptic bronchoscopy, bronchoalveolar lavage, ${ }^{67}$ and laboratory processing of bronchoalveolar lavage fluid, transbronchial, open lung, and percutaneous biopsy specimens were as previously described. ${ }^{78}$

A diagnosis of $P$ carinii pneumonia was made if organisms were identified by methenamine silver staining of induced sputum, bronchoalveolar lavage or biopsy material, or a response was seen to specific treatment for pneumocystis pneumonia, ${ }^{67}$ or both (in the 1990-1 study some patients with a clinical response to treatment but a negative methenamine stain had the diagnosis made by DNA amplification). ${ }^{9}$

Bronchitis was diagnosed if patients had cough and dyspnoea with expectoration of purulent sputum, with or without fever, and a normal chest radiograph, if the silver stain of bronchoalveolar lavage fluid was negative for $P$ carinii, and patients responded to oral antibiotics in conventional doses. A diagnosis of bacterial pneumonia was made if patients had fever or pleuritic pain (with or without purulent sputum) and focal or diffuse chest radiographic abnormalities, with either positive culture of a bacterial pathogen from bronchoalveolar lavage fluid and a negative silver stain, or negative bronchoalveolar 
lavage culture and a response to antibiotics in conventional doses. None of these patients were treated with drugs effective against $P$ carinii.

Kaposi's sarcoma was diagnosed on the basis of visual identification at bronchoscopy of typical red or violaceous raised or plaque like lesions in the tracheobronchial tree. ${ }^{10}$

\section{Results}

During the 1986-7 study there were 73 admissions for respiratory investigations representing $34 \%$ of all admissions in HIV positive patients; all were homosexual men. In the 1990-1 study 122 patients were investigated. Of these, two were female heterosexuals (one from Africa), one was a male intravenous drug user, one a bisexual male, and one a male with no apparent risk factors for HIV infection; the remaining 117 were homosexual men. Respiratory episodes represented $27 \%$ of all admissions in the 1990-1 study. The patients' diagnoses are shown in the table.

\section{PNEUMOCYSTIS CARINII PNEUMONIA}

In both study periods $P$ carinii pneumonia was the commonest diagnosis (table). Of the 59 patients with $P$ carinii pneumonia in the 1990-1 study, at the time of diagnosis 16 had received prophylaxis with co-trimoxazole (eight of these had also received zidovudine),
14 had received nebulised pentamidine (seven of whom had also had zidovudine), three patients had received zidovudine only, and 26 patients had received neither zidovudine nor prophylaxis again pneumocystis pneumonia. In the 1986-7 study no patient was receiving prophylaxis for pneumocystis pneumonia.

\section{MYCOBACTERIAL INFECTIONS}

In four of the six patients with Mycobacterium avium intracellulare in bronchoalveolar lavage the organism was also identified in blood and hence was part of a disseminated infection. $M$ tuberculosis was identified in bronchoalveolar lavage fluid in four patients (as a copathogen with $P$ carinii in one patient).

\section{MALIGNANCY}

All of the patients with bronchial Kaposi's sarcoma also had palatal and cutaneous lesions of Kaposi's sarcoma. Two of the three patients in the 1986-7 study had co-infection as did three of 15 patients in the 1990-1 study. Two patients had non-Hodgkin's lymphoma diagnosed by open lung biopsy after bronchoscopy failed to establish the diagnosis.

\section{BACTERIAL INFECTIONS}

In the 1986-7 study bacterial infection accounted for only two episodes of pneumonia and eight episodes of bronchitis. In the

Diagnoses in patients presenting with respiratory episodes in 1986-7 and 1990-1

\begin{tabular}{|c|c|c|}
\hline Diagnosis & $\begin{array}{l}1986-7 \\
(n=73)\end{array}$ & $\begin{array}{l}1990-1 \\
(n=122)\end{array}$ \\
\hline P carinii pneumonia & $\begin{array}{l}50 \\
1 \text { also had } M \text { tuberculosis } \\
1 \text { also had } S \text { aureus pneumonia }\end{array}$ & $\begin{array}{l}59 \\
1 \text { also had } H \text { influenzae bronchitis } \\
1 \text { also had } C \text { neoformans } \\
1 \text { also had Kaposi's sarcoma }\end{array}$ \\
\hline Kaposi's sarcoma & $\begin{array}{l}3 \text { also had } S \text { aureus bronchitis } \\
1 \text { also had } B \text { catarrhalis bronchitis }\end{array}$ & $\begin{array}{l}14 \text { also had } S \text { aureus bronchitis } \\
1 \text { also had } C M V \text { pneumonitis }\end{array}$ \\
\hline $\begin{array}{l}\text { Mycobacterial infection } \\
M \text { tuberculosis } \\
M \text { avium intracellulare } \\
\text { M kansasii }\end{array}$ & $\begin{array}{l}2 \\
1 \text { also had } S \text { aureus and } \\
H \text { influenzae bronchitis }\end{array}$ & $\begin{array}{l}8 \\
3 \\
4\end{array}$ \\
\hline $\begin{array}{l}\text { Bacterial infection } \\
\text { (a) Pneumonia } \\
\text { S aureus } \\
\text { Ps aeruginosa } \\
\text { Str pneumoniae } \\
\text { H influenzae }\end{array}$ & 1 also had CMV pneumonitis & $\begin{array}{l}26 \\
19 \\
5 \\
4 \\
4 \\
2 \\
1 \text { also had CMV pneumonitis }\end{array}$ \\
\hline $\begin{array}{l}\text { Lobar pneumonia } \\
\text { (negative lavage) } \\
\text { (b) Bronchitis }\end{array}$ & 4 & $\begin{array}{l}4 \\
7\end{array}$ \\
\hline $\begin{array}{l}\text { Other diagnoses } \\
\text { Severe undiagnosed pneumonia } \\
\text { Lymphoid interstitial pneumonitis } \\
\\
\text { Non-Hodgkin's lymphoma } \\
\text { Chronic inflammation } \\
\text { Non-specific fibrosis } \\
\text { Bronchiolitis } \\
\text { C neoformans pneumonia } \\
\text { Penicillium marneffei } \\
\text { CMV pneumonitis } \\
\text { Aspirated food } \\
\text { Actinomyocosis }\end{array}$ & $\begin{array}{l}10 \\
3 \\
3 \\
1 \text { also had } B \text { catarrhalis bronchitis } \\
2 \\
1\end{array}$ & $\begin{array}{l}2 \\
1 \\
1 \\
1 \\
1 \\
1 \\
1\end{array}$ \\
\hline $\begin{array}{l}\text { Negative investigations/self limiting } \\
\text { episode }\end{array}$ & 3 & 7 \\
\hline
\end{tabular}

CMV-cytomegalovirus 
1990-1 study 28 patients had a bacterial infection of whom 12 had received daily cotrimoxazole (five also zidovudine) as prophylaxis against pneumocystis pneumonia (two others had received nebulised pentamidine, one zidovudine and dapsone, and five zidovudine only). Staphylococcus aureus was the commonest cause of pneumonia, occurring in five patients of whom two were bacteraemic (one of these patients was receiving ganciclovir and was neutropenic). Two of the four patients with Pseudomonas aeruginosa pneumonia were bacteraemic. None of the four patients with Streptococcus pneumoniae pneumonia was neutropenic, but one patient was bacteraemic. Four other patients had lobar pneumonia; all were pyrexial and had a peripheral blood polymorph leucocytosis. Staining and culture of bronchoalveolar lavage fluid was negative but revealed a neutrophil inflammatory response. Two of these had commenced oral antibiotics before admission; blood cultures in all four patients were negative.

\section{OTHER CONDITIONS}

The patient in whom bronchiolitis was the final diagnosis presented in 1991 with a clinical picture suggestive of pneumocystis pneumonia, but after two negative bronchoscopies and failure to improve on intravenous pentamidine he underwent open lung biopsy which provided the diagnosis. Two other patients in the 1990-1 study presented with dyspnoea and diffuse reticulonodular shadowing on the chest radiograph. Culture of bronchoalveolar lavage fluid and of peripheral blood grew Cryptococcus neoformans in both patients; one patient had co-infection with $P$ carinii. Another patient presented in the 1991 study with fever, rigors and an unproductive cough. Chest examination, arterial blood gases, a chest radiograph and computed tomographic scan of the thorax all gave normal results. Culture of bronchoalveolar lavage fluid and peripheral blood grew Penicillium marneffei.

Ten patients who had presented with acute respiratory symptoms and non-specific or normal chest radiographs had negative investigations including culture of blood, throat swab, and urine, in addition to negative results from bronchoscopy. None received treatment and their symptoms were self limiting; none presented again with respiratory symptoms within eight weeks.

\section{Discussion}

In our study we have shown that pneumocystis pneumonia remains the commonest diagnosis in an HIV antibody positive population largely composed of homosexual males presenting with respiratory episodes. Compared with other diagnoses this infection was less common in the 1990-1 study than in the 1986-7 study. These data are in contrast to the results of two recent studies.

In the first study of HIV antibody positive patients in Edinburgh presenting with respi- ratory problems from 1985 to 1989 of whom $72 \%$ were intravenous drug users ${ }^{11}$ only $27 \%$ of the 180 respiratory episodes were due to pneumocystis pneumonia and $54 \%$ were due to bacterial chest infections, the commonest pathogens being Haemophilus influenzae and Streptococcus pneumoniae. Of the patients with bacterial chest infections, $50 \%$ had pneumonia defined by the presence of focal consolidations on the chest radiograph.

The second study from France reported 132 consecutive episodes of respiratory illness in $101 \mathrm{HIV}$ antibody positive patients during the period 1989-90.12 Eighty three patients were male and 71 had a prior AIDS defining illness; 57 patients were intravenous drug users and 34 were homosexual or bisexual men. Bacterial pneumonia was the commonest cause of presentation in this study accounting for 60 episodes (45.5\%); Str pneumoniae and $H$ influenzae were the commonest pathogens. $P$ carinii pneumonia accounted for only 36 episodes (27\%).

In both of these studies the majority of patients were intravenous drug users and it is likely that the high incidence of bacterial infection is attributable to the effects of intravenous drug use and not simply to HIV infection. ${ }^{12}{ }^{13}$ In our study the majority of patients were homosexual men and those patients with bacterial pneumonia due to $S$ aureus and Ps aeruginosa had advanced HIV disease. A study from New York by Whimbey et al of bacterial infections in 336 patients with AIDS ( $95 \%$ of whom were homosexual men) reported only eight patients with bacteraemia and pneumonia. ${ }^{14}$ As all the patients in this study had AIDS, by definition they had advanced HIV disease. Two episodes of pneumonia were due to Str pneumonia and one to $H$ influenzae. Of two patients with $P_{S}$ aeruginosa pneumonia one was neutropenic and all three patients with $S$ aureus had pulmonary Kaposi's sarcoma.

We observed that Kaposi's sarcoma represented a larger proportion of patients in the cohort seen in the 1990-1 study. Although we did not specifically look for evidence of stage of disease at presentation with respiratory illness, nor did we record CD4 (T helper lymphocyte) counts, it is possible that patients in the second study had more advanced HIV disease. As patients are presenting to physicians earlier in the course of their disease and are given antiretroviral therapy and primary prophylaxis of opportunistic infection so their survival is increased and they may now progress to develop Kaposi's sarcoma or lymphoma. ${ }^{235}$

In North America cryptococcal pulmonary infection has accounted for $2-15 \%$ of all AIDS patients presenting with pneumonia. ${ }^{15}$ In the UK cryptococcal pulmonary infection is rare and these are the first patients in whom-we have seen this infection. The presentation in our patients was typical of that previously reported, the chest radiograph showing reticulonodular interstitial infiltrates and the pulmonary infection was part of a systemic infection. ${ }^{16} P$ marneffei infection has 
recently been reported in association with HIV infection in five patients in south east Asia. ${ }^{17}$ The patient in our study with this organism had travelled widely in Thailand before his admission.

Although we have recently seen a small overall increase in $M$ tuberculosis in our HIV antibody positive patient population ${ }^{18}$ this is not reflected in our study. The explanation for this is that of all HIV antibody positive patients with $M$ tuberculosis $68 \%$ had extrapulmonary disease and of those with pulmonary disease the most frequent presentation was unexplained fever; very few patients had respiratory symptoms or signs. ${ }^{18}$

Our study has shown that pneumocystis pneumonia remains the commonest cause of respiratory illness in an HIV positive population largely composed of homosexual men. An increase in bacterial infections was also noted. The increased number of patients with pulmonary Kaposi's sarcoma and the occurrence of lymphoma probably reflect the benefits of early intervention with antiretroviral therapy and with prophylaxis of opportunistic infections.

We thank Jane Catchpole for help with collecting data and for typing the manuscript.

1 Leoung GS, Feigal DW, Montgomery AB, Corkery K, Wardlaw L, Adams M, et al. Aerosolized pentamidine for prophylaxis against Pneumocystis carinii pneumonia. N Engl f Med 1990;323:769-75.

2 Fischl MA, Dickinson GM, LaVoie L. Safety and efficacy of sulfamethoxazole-trimethoprim chemoprophylaxis for Pneumocystis carinii pneumonia. JAMA 1988;259: 1185.

3 Fischl MA, Richman DD, Grieco MH, Gottlieb MS, Volberding PA, Laskin OL, et al. The efficacy of azidothymidine (AZT) in the treatment of patients with AIDS and AIDS-related complex. $N$ Engl $\mathscr{F} \mathrm{Med} 1987$;
317:185-91.

4 Robinson DS, Cunningham DA, Dave S, Flemming J, Mitchell DM. Diagnostic value of lung clearance of ${ }^{\omega} \mathrm{m}$ Tc DTPA compared with other non-invasive investigations in Pneumocystis carinii pneumonia in AIDS. Thorax 1991;46:722-6.

5 Peters BS, Beck EJ, Coleman DG, Wadsworth MJH, McGuiness O, Harris JRW, et al. Changing disease patterns in patients with AIDS in a referral centre in the
United Kingdom: the changing face of AIDS. BMF 1991;302:203-7.

6 Miller RF, Millar AB, Weller IVD, Semple SJG. Empirical treatment without bronchoscopy for Pneumocystis carinii pneumonia in the acquired immunodeficiency syndrome. Thorax 1989;44:559-64.

7 Miller RF, Kocjan G, Buckland J, Holton J, Malin A, Semple SJG. Sputum induction for the diagnosis of pulmonary disease in HIV positive patients. $\mathcal{F}$ Infect 1991; 23:5-15.

8 Griffiths MH, Kocjan G, Miller RF, Godfrey-Faussett P. Diagnosis of pulmonary disease in human immunodeficiency virus infection: the role of transbronchial biopsy and bronchoalveolar lavage. Thorax 1989;44:554-8.

9 Wakefield AE, Pixley FJ, Banerii S, Miller RF, Moxon ER, Hopkin JM. Detection of Pneumocystis carinii with DNA amplification. Lancet 1990;336:451-3.

10 Hughes-Davies L, Kocjan G, Spittle MF, Miller RF. Occult alveolar haemorrhage in bronchopulmonary Kaposi's sarcoma. $\mathcal{f}$ Clin Pathol 1992;45:536-7.

11 Willcox L, Cowan F, Brettle RP, Emanuel FXS, Flegg PG, Burns S. The spectrum of chest infections in HIV positive patients in Edinburgh. F Infect 1992;24:37-42.

12 Magnenat J-L, Nicod LP, Auckenthaler R, Junod AF. Mode of presentation and diagnosis of bacterial pneumonia in human immunodeficiency virus infected patients. Am Rev Respir Dis 1991;144:917-22.

13 Selwyn PA, Feingold AR, Hartel D, Schoenbaum EE, Alderman MH, Klein RS, et al. Increased risk of bacterial pneumonia in HIV-infected intravenous drug users without AIDS. AIDS 1988;2:267-72.

14 Whimbey E, Gold JWM, Polsky B, Dryjanski J, Hawkins $\mathrm{C}$, Blevins $\mathrm{A}$, et al. Bacteremia and fungemia in patients with the acquired immunodeficiency syndrome. Ann Intern Med 1986;104:511-14.

15 Murray JF, Felton CP, Garay SM, Gottlieb MS, Hopewell PC, Stover DE, et al. Pulmonary complications of the acquired immunodeficiency syndrome: report of the National Heart, Lung and Blood Institute. N Engl $\mathcal{F}$ Med 1984;310:1682-8.

16 Miller WT, Edelman JM, Miller WT. Cryptococcal pulmonary infection in patients with AIDS: radiographic appearance. Radiology 1990;175:725-8.

$17 \mathrm{Li}$ PCK, Tsui MS, Ma KF. Penicillium marneffei: indicator disease for AIDS in south east Asia. AIDS 1992;6: 240-1.

18 Foley NM, Miller RF. Tuberculosis and AIDS: is the "white plague" up and coming? I Infect 1993;26:39-43. 